\title{
The Association of Intrapair Birth-Weight Differences With Internalizing and Externalizing Behavior Problems
}

Citation for published version (APA):

Tore, E. C., Antoniou, E. E., Reed, K., Southwood, T. R., Smits, L., McCleery, J. P., \& Zeegers, M. P. (2018). The Association of Intrapair Birth-Weight Differences With Internalizing and Externalizing Behavior Problems. Twin Research and Human Genetics, 21(3), 253-262. https://doi.org/10.1017/thg.2018.13

Document status and date:

Published: 01/06/2018

DOI:

10.1017/thg.2018.13

Document Version:

Publisher's PDF, also known as Version of record

\section{Document license:}

Taverne

Please check the document version of this publication:

- A submitted manuscript is the version of the article upon submission and before peer-review. There can be important differences between the submitted version and the official published version of record.

People interested in the research are advised to contact the author for the final version of the publication, or visit the DOI to the publisher's website.

- The final author version and the galley proof are versions of the publication after peer review.

- The final published version features the final layout of the paper including the volume, issue and page numbers.

Link to publication

\footnotetext{
General rights rights.

- You may freely distribute the URL identifying the publication in the public portal. please follow below link for the End User Agreement:

www.umlib.nl/taverne-license

Take down policy

If you believe that this document breaches copyright please contact us at:

repository@maastrichtuniversity.nl

providing details and we will investigate your claim.
}

Copyright and moral rights for the publications made accessible in the public portal are retained by the authors and/or other copyright owners and it is a condition of accessing publications that users recognise and abide by the legal requirements associated with these

- Users may download and print one copy of any publication from the public portal for the purpose of private study or research.

- You may not further distribute the material or use it for any profit-making activity or commercial gain

If the publication is distributed under the terms of Article $25 \mathrm{fa}$ of the Dutch Copyright Act, indicated by the "Taverne" license above, 


\title{
The Association of Intrapair Birth-Weight Differences With Internalizing and Externalizing Behavior Problems
}

\author{
Elena C. Tore, ${ }^{1,2}$ Evangelia E. Antoniou, ${ }^{1}$ Keith Reed, ${ }^{3}$ Taunton R. Southwood, ${ }^{4}$ Luc Smits, ${ }^{5}$ \\ Joseph P. McCleery, ${ }^{6}$ and Maurice P. Zeegers ${ }^{1,7}$ \\ ${ }^{1}$ Department of Complex Genetics, Care and Public Health Research Institute (School CAPHRI), Maastricht University, \\ Maastricht, the Netherlands \\ ${ }^{2}$ Institute of Applied Health Research, College of Medical and Dental Sciences, University of Birmingham, Birmingham, UK \\ ${ }^{3}$ Twins and Multiple Births Association, The Manor House, Church Hill, Aldershot, UK \\ ${ }^{4}$ Institute of Child Health, University of Birmingham, Birmingham, UK \\ ${ }^{5}$ Department of Epidemiology, Care and Public Health Research Institute (CAPHRI), Maastricht University, Maastricht, the \\ Netherlands \\ ${ }^{6}$ Developmental and Behavioral Pediatrics, Children's Hospital of Philadelphia, Philadelphia, Pennsylvania, USA \\ ${ }^{7}$ Department of Complex Genetics, Nutrition and Translational Research in Metabolism (School NUTRIM), Maastricht \\ University, Maastricht, the Netherlands
}

Problem behaviors are of increasing public health concern. Twin studies have revealed substantial genetic and environmental influences on children's behavior, and examining birth-weight difference could allow the identification of the specific contribution of multiple non-shared prenatal environmental factors. The Twins and Multiple Births Association Heritability Study, a UK, volunteer-based study, recruited mothers of twins aged 18 months to 5 years; 960 twins (480 pairs) were included in the analysis. Twins' mothers answered questions relative to their pregnancy and their twins' characteristics, and completed the Child Behavior Checklist (CBCL) 1 1/2-5. The association between the absolute birth-weight difference and each $\mathrm{CBCL}$ scale's score difference was analyzed by means of multiple linear regressions. Expected mean $\mathrm{CBCL}$ score differences were calculated. In monozygotic (MZ) twins, statistically and clinically significant associations were found between intrapair birth-weight difference and difference in total problems, internalizing problems, and emotional reactiveness. No significant results were observed neither in dizygotic (DZ) twins when analyzed as a separate group nor in MZ and DZ twins combined. The results of the present study suggest that with increasing the absolute birth-weight difference, the intrapair difference in total problems, internalizing behaviors and emotionality increases, with smaller twins being at major risk for later behavior problems. Moreover, these results suggest a causal association between birth weight and behavior development.

Keywords: twins, birth-weight discordance, intrauterine environment, problem behavior, child behavior checklist

Behavior problems, such as internalizing (i.e., anxiety, depression, emotional problems, somatic complaints, and withdrawnness) and externalizing (i.e., aggression and attention problems) behaviors, may manifest during the preschool years, potentially extending over childhood and adolescence (Bartels et al., 2004). Early identification and deeper understanding of the etiology of these behaviors are important, mainly because children with behavior difficulties are at a greater risk of adverse developmental outcomes, including poor academic performance, conflictual relationships with peers and family members, delinquency, and even early death (Jokela et al., 2009; Sourander et al., 2007; Van Der Ende et al., 2016).

RECEIVED 4 December 2017; ACCEPTED 21 February 2018. First published online 12 April 2018.

ADDRESS FOR CORRESPONDENCE: Elena Tore, Department of Complex Genetics, Care and Public Health Research Institute (School CAPHRI), Maastricht University, 6200 MD Maastricht, the Netherlands. E-mail: e.tore@maastrichtuniversity.nl 
Twin studies have revealed significant genetic influences on internalizing and externalizing behaviors, with common and non-shared environmental effects generally being considered more modest (Bartels et al., 2004; van der Valk et al., 1998). Among the diverse mechanisms via which the environment can influence twins' behavior, the prenatal environment is receiving increasing interest (Knopik et al., 2016). In this context, birth-weight discordance is considered a good proxy of the non-shared environment's effect. In fact, as twins are characterized by the same gestational age, a difference in their birth weight is the result of any factor affecting the growth of each individual twin (Pettersson et al., 2015). These factors could be ascribed to genetic or structural abnormalities, or to adverse intrauterine factors, such as small placental weight, single umbilical artery, excessive velamentous cord insertions (Victoria et al., 2001), or to various placental abnormalities (Kent et al., 2012), which may randomly affect only one twin in a pair.

Growth discordance has been associated with impaired cognitive development (Ross et al., 2012), ADHD symptoms (Pettersson et al., 2015), and problem behaviors (Mankuta et al., 2010; van Os et al., 2001). In particular, van Os et al. (2001) analyzed the association between birth-weight difference and Child Behavior Checklist (CBCL) total score difference in 745 twin pairs from the East Flanders Prospective Twin Survey (EFPTS), observing a positive association between the intrapair behavior-problem difference and the degree of birth-weight discordance.

The aim of the current study was to replicate the previously reported association between the intrapair birthweight difference and the intrapair difference in behavior problems, measured by the CBCL questionnaire. Our primary interest was to examine whether and how birthweight difference and other perinatal factors, including gestational age, maternal smoking, and BMI before pregnancy, may affect the development of problematic behaviors. Specifically, we focused on each CBCL subscale and presented the absolute birth-weight differences in order to help parents and clinicians to easily identify the more challenging areas of development. Furthermore, we concentrated on young, preschool-aged twins to reduce as much as possible external, non-controlled for influences.

\section{Materials and Methods}

The data collection process has been described previously (Antoniou et al., 2014). Briefly, the Twins and Multiple Births Association Heritability Study (TAMBAHS) is a UK, volunteer-based study investigating the psychological development of twins from birth until 5 years of age. Mothers of twins aged 18 months to 5 years were selected for this study. Between July 2008 and May 2010, 492 moth- ers completed an online questionnaire on their twins' emotional and behavioral development. Participants' geographical spread was representative of the twin families' spread across the UK.

\section{Zygosity Determination}

The adapted version of the Goldsmith's zygosity questionnaire (Goldsmith, 1991) was used to assess the zygosity of the twins included in the TAMBAHS dataset. This questionnaire has been validated against determination by identity of polymorphic DNA markers, reaching an accuracy of verifying zygosity in $95 \%$ of cases.

\section{Behavior Problems}

The CBCL 1 1/2-5 (Achenbach \& Rescorla, 2000) is a questionnaire developed to obtain a standardized report of children's behavior problems as perceived by their parents. Numerous versions of this questionnaire have been developed to target different age groups. The CBCL $1 \frac{1}{2}-5$ was developed to assess children from 18 months to 5 years of age. It contains 99 problem items, split into 7 subscales: emotionally reactive, anxious/depressed, somatic complaints, withdrawn, sleep problems, attention problems, and aggressive behavior, originally derived by factor analyses. The broadband scale 'Internalizing' is the sum score of the first four syndrome scales, whereas 'Externalizing' is the sum score of attention problems and aggressive behavior. 'Total problems' is the sum score of all 99 problem items. Each item is scored 0-2 (not true, somewhat or sometimes true, and very true or often true), based on the preceding 2 months. Good reliability and validity criteria have been reported for this checklist (Achenbach \& Rescorla, 2000).

\section{Statistical Analysis}

Twins' absolute birth-weight difference in grams (i.e., birth weight of the larger twin - birth weight of the smaller twin) and CBCL score discordance (i.e., CBCL score of the larger twin - CBCL score of the smaller twin) were calculated. The association between birth-weight difference and CBCL score difference was investigated by the means of multiple linear regression analysis. The hypothesis under test was that an increase in birth-weight difference between co-twins will be associated with a CBCL score difference. The expected mean CBCL difference was calculated to determine how the score is expected to change with increasing birth-weight difference per $100 \mathrm{~g}$ difference. Twins' gender (male-male, female-female, opposite-sex), age, gestational age, weight difference at the time of survey, zygosity, and maternal prepregnancy BMI, age, and smoking status before, during and after pregnancy were controlled for in the analysis. An interaction term was added to the regressions in order to test the possible interaction of zygosity with birth-weight difference.

Statistical analysis was performed in Stata v.13 (StataCorp, 2013). Alpha was set at 0.05 . 
TABLE 1

Phenotypic Characteristics of Twins According to their Zygosity

\begin{tabular}{|c|c|c|c|c|c|c|}
\hline \multirow{2}{*}{$\begin{array}{l}\text { Twins' characteristics } \\
\text { Gender }\end{array}$} & & \multicolumn{2}{|c|}{$\mathrm{MZ}$} & \multicolumn{2}{|c|}{$\mathrm{DZ}$} & \\
\hline & & $n$ & $\%$ & $n$ & $\%$ & \\
\hline & Male & 202 & 57.06 & 301 & 49.67 & \\
\hline & Female & 152 & 42.94 & 305 & 50.33 & \\
\hline & Same-sex pairs & 177 & 100 & 164 & 54.13 & \\
\hline & Different-sex pairs & NA & NA & 139 & 45.87 & \\
\hline & & Mean & $S D$ & Mean & $S D$ & $p$ value \\
\hline Birth weight (g) & & $2,326.64$ & 575.86 & $2,487.02$ & 578.78 & $<.0001$ \\
\hline Gestational age (weeks) & & 35.38 & 2.48 & 36.26 & 2.69 & $<.0001$ \\
\hline Children age (months) & & 37.50 & 11.63 & 34.67 & 11.35 & .0003 \\
\hline Twins' weight (Kg) & & 11.25 & 11.74 & 10.51 & 6.59 & .235 \\
\hline CBCL scales & & Mean $^{a}$ & SE & Mean $^{a}$ & SE & $p$ value ${ }^{a}$ \\
\hline \multicolumn{7}{|l|}{ Externalizing } \\
\hline \multirow{2}{*}{ Attention problems } & Males & 2.46 & 0.13 & 2.45 & 0.11 & .931 \\
\hline & Females & 2.22 & 0.17 & 2.26 & 0.12 & .844 \\
\hline \multirow[t]{2}{*}{ Aggressive behavior } & Males & 11.08 & 0.42 & 10.35 & 0.35 & .190 \\
\hline & Females & 10.13 & 0.51 & 10.18 & 0.37 & .935 \\
\hline \multirow[t]{2}{*}{ Total externalizing } & Males & 13.58 & 0.50 & 12.83 & 0.42 & .255 \\
\hline & Females & 12.40 & 0.61 & 12.46 & 0.44 & .941 \\
\hline \multicolumn{7}{|l|}{ Internalizing } \\
\hline \multirow[t]{2}{*}{ Emotional reactiveness } & Males & 1.44 & 0.15 & 1.31 & 0.12 & .519 \\
\hline & Females & 1.80 & 0.20 & 1.35 & 0.14 & .065 \\
\hline \multirow[t]{2}{*}{ Anxiety/depression } & Males & 2.15 & 0.15 & 2.34 & 0.13 & .356 \\
\hline & Females & 3.17 & 0.20 & 2.20 & 0.14 & $<.001$ \\
\hline \multirow[t]{2}{*}{ Somatic complaints } & Males & 1.75 & 0.14 & 1.90 & 0.12 & .403 \\
\hline & Females & 2.03 & 0.17 & 1.95 & 0.12 & .685 \\
\hline \multirow[t]{2}{*}{ Withdrawn } & Males & 1.20 & 0.10 & 1.37 & 0.09 & .215 \\
\hline & Females & 1.82 & 0.12 & 1.27 & 0.09 & $<.001$ \\
\hline \multirow[t]{2}{*}{ Total internalizing } & Males & 6.56 & 0.37 & 6.96 & 0.31 & .422 \\
\hline & Females & 8.90 & 0.51 & 6.80 & 0.36 & .001 \\
\hline \multirow[t]{2}{*}{ Sleep problems } & Males & 2.53 & 0.16 & 2.24 & 0.14 & .173 \\
\hline & Females & 2.58 & 0.20 & 2.41 & 0.14 & .503 \\
\hline \multirow[t]{2}{*}{ Total problems } & Males & 32.71 & 1.11 & 32.14 & 0.95 & .699 \\
\hline & Females & 34.69 & 1.43 & 31.11 & 1.02 & .042 \\
\hline \multirow[t]{2}{*}{ Maternal characteristics } & & $\mathrm{MZ}$ & & $\mathrm{DZ}$ & & \\
\hline & & Mean & $S D$ & Mean & $S D$ & $p$ value \\
\hline Age & & 35.53 & 4.69 & 36.69 & 4.17 & .0002 \\
\hline \multirow[t]{2}{*}{ Prepregnancy BMI } & & 24.52 & 4.32 & 24.76 & 5.11 & .570 \\
\hline & & $n$ & $\%$ & $n$ & $\%$ & \\
\hline \multirow[t]{2}{*}{ Ethnicity } & White & 346 & 97.19 & 610 & 98.07 & \\
\hline & Other & 10 & 2.81 & 12 & 1.82 & \\
\hline \multirow[t]{4}{*}{ Smoking status } & & Yes (\%) & No (\%) & Yes (\%) & No (\%) & \\
\hline & Before & 78 (22.94) & $262(77.06)$ & $108(17.94)$ & $494(82.06)$ & \\
\hline & During & $8(2.50)$ & $312(97.50)$ & $20(3.56)$ & $542(96.44)$ & \\
\hline & After & $34(10.69)$ & $284(89.31)$ & $58(9.63)$ & $526(90.07)$ & \\
\hline
\end{tabular}

Note: $S D=$ standard deviation; $S E=$ standard error.

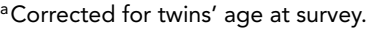

\section{Results}

\section{Summary Statistics}

A total of 960 twins were included in the analysis, of which 202 were monozygotic (MZ) male twins, $152 \mathrm{MZ}$ female twins, 162 dizygotic (DZ) male twins, 166 DZ female twins, and 278 opposite-sex twins. Mean twins' birth weight, gestational age, and age at survey are presented in Table 1, subdivided by zygosity. MZ twins' mean gestational age was significantly shorter than that of DZ twins $(35.38 \pm 2.48$ weeks of $\mathrm{MZ}$ twins, compared to $36.26 \pm 2.69$ weeks of DZ twins; $p=.0001)$. Furthermore, MZ twins' mean birth weight was significantly lower than that of DZ twins $(2,326.64 \pm 575.86 \mathrm{~g}$ compared to $2,487.02 \pm 578.78 \mathrm{~g}$ for MZ and DZ twins, respectively; $p=.0001$ ), while MZ twins' age at the time of survey was significantly higher than DZ twins' mean age $(37.50 \pm 11.63$ months and $34.67 \pm 11.35$ months for MZ and DZ twins, respectively; $p=.0003$ ). Table 1 also shows mean CBCL scores for each zygosity group, subdivided by gender and adjusted for age at survey to account for the rapid development that occurs in the age period considered. As can be seen, mean scores were statistically significantly higher in female MZ twins as compared to female DZ twins in total problems (34.69 [1.43] compared to 31.11 [1.02] for female $\mathrm{MZ}$ and $\mathrm{DZ}$ twins, respectively; $p=.042)$, internalizing problems $(8.90$ [0.51] and 6.80 [0.36] for female $\mathrm{MZ}$ and $\mathrm{DZ}$ twins, respectively; $p=.001$ ), anxiety/depression (3.17 [0.20] for female $\mathrm{MZ}$ twins and 2.20 [0.14] for female DZ twins; $p=.001$ ) and withdrawnness (1.82 [0.12] for female MZ twins and 1.27 [0.09] for female DZ twins; $p=.001)$. No statistically 
TABLE 2

Phenotypic Discordance According to Zygosity

\begin{tabular}{|c|c|c|c|c|c|c|}
\hline \multirow[b]{2}{*}{ Twins' characteristics } & & \multicolumn{2}{|c|}{$\mathrm{MZ}$} & \multicolumn{2}{|c|}{$\mathrm{DZ}$} & \multirow[b]{2}{*}{$p$ value } \\
\hline & & Mean & $S D$ & Mean & $S D$ & \\
\hline \multirow[t]{2}{*}{ Birth-weight difference (g) } & & 246.07 & 228.48 & 295.65 & 271.74 & .004 \\
\hline & & $n$ & $\%$ & $n$ & $\%$ & \\
\hline \multicolumn{7}{|c|}{ Birth-weight difference categories } \\
\hline $0 \mathrm{~g}$ & & 18 & 5 & 46 & 7.37 & \\
\hline $0-100 \mathrm{~g}$ & & 96 & 26.67 & 120 & 19.23 & \\
\hline $100-200 \mathrm{~g}$ & & 84 & 23.33 & 118 & 18.91 & \\
\hline $200-300 \mathrm{~g}$ & & 44 & 12.22 & 76 & 12.18 & \\
\hline $300-400 \mathrm{~g}$ & & 48 & 13.33 & 84 & 13.46 & \\
\hline $400-500 \mathrm{~g}$ & & 24 & 6.67 & 60 & 9.62 & \\
\hline $500-600 \mathrm{~g}$ & & 6 & 1.67 & 40 & 6.41 & \\
\hline $600-700 \mathrm{~g}$ & & 4 & 1.11 & 16 & 2.56 & \\
\hline $700-800 \mathrm{~g}$ & & 22 & 6.11 & 10 & 1.60 & \\
\hline $800-900 \mathrm{~g}$ & & 4 & 1.11 & 10 & 1.60 & \\
\hline $900-1,000 \mathrm{~g}$ & & 2 & 0.56 & 6 & 0.96 & \\
\hline $1,000-1,100 \mathrm{~g}$ & & 0 & 0 & 8 & 1.28 & \\
\hline$>1,100 \mathrm{~g}$ & & 8 & 2.22 & 30 & 4.81 & \\
\hline CBCL scales & & Mean $^{a}$ & SE & Mean ${ }^{a}$ & $S E$ & $p$ value ${ }^{a}$ \\
\hline \multirow[t]{3}{*}{ Attention problems } & Male & 0.06 & 0.17 & -0.12 & 0.20 & .459 \\
\hline & Female & 0.13 & 0.26 & -0.00 & 0.25 & .711 \\
\hline & Opposite sex & & & 0.24 & 0.18 & - \\
\hline \multirow[t]{3}{*}{ Aggressive behavior } & Male & 0.10 & 0.43 & -0.31 & 0.51 & .542 \\
\hline & Female & 0.10 & 0.56 & -0.45 & 0.54 & .473 \\
\hline & Opposite sex & & & -0.15 & 0.37 & - \\
\hline \multirow[t]{3}{*}{ Total externalizing } & Male & 0.16 & 0.50 & -0.42 & 0.58 & .451 \\
\hline & Female & 0.19 & 0.65 & -0.45 & 0.63 & .477 \\
\hline & Opposite sex & & & -0.08 & 0.47 & - \\
\hline \multirow[t]{3}{*}{ Emotional reactiveness } & Male & -0.11 & 0.36 & 0.56 & 0.43 & .238 \\
\hline & Female & 1.40 & 0.51 & -0.40 & 0.49 & .012 \\
\hline & Opposite sex & & & -0.19 & 0.25 & - \\
\hline \multirow[t]{3}{*}{ Anxiety/depression } & Male & 0.07 & 0.21 & -0.12 & 0.24 & .553 \\
\hline & Female & -0.12 & 0.25 & 0.20 & 0.24 & .353 \\
\hline & Opposite sex & & & -0.15 & 0.16 & - \\
\hline \multirow[t]{3}{*}{ Somatic complaints } & Male & -0.01 & 0.21 & 0.37 & 0.25 & .240 \\
\hline & Female & -0.48 & 0.28 & 0.67 & 0.28 & .004 \\
\hline & Opposite sex & & & 0.15 & 0.19 & - \\
\hline \multirow[t]{3}{*}{ Withdrawn } & Male & 0.19 & 0.13 & -0.34 & 0.16 & .011 \\
\hline & Female & 0.13 & 0.15 & -0.38 & 0.15 & .016 \\
\hline & Opposite sex & & & 0.08 & 0.11 & - \\
\hline \multirow[t]{3}{*}{ Total internalizing } & Male & 0.15 & 0.53 & 0.47 & 0.62 & .695 \\
\hline & Female & 0.96 & 0.79 & 0.09 & 0.77 & .432 \\
\hline & Opposite sex & & & -0.14 & 0.43 & - \\
\hline \multirow[t]{3}{*}{ Sleep problems } & Male & -0.14 & 0.16 & 0.33 & 0.18 & .051 \\
\hline & Female & -0.46 & 0.25 & -0.00 & 0.24 & .180 \\
\hline & Opposite sex & & & 0.17 & 0.17 & - \\
\hline \multirow[t]{3}{*}{ Total problems } & Male & 0.73 & 1.02 & 0.94 & 1.20 & .892 \\
\hline & Female & 0.93 & 1.34 & -0.14 & 1.30 & .565 \\
\hline & Opposite sex & & & 0.10 & 0.84 & - \\
\hline
\end{tabular}

Note: $S D=$ standard deviation; $S E=$ standard error.

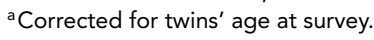

significant difference in mean scores was observed among male twins.

DZ twins' mothers were significantly older than mothers of MZ twins ( $36.69 \pm 4.17$ years compared to $35.53 \pm 4.69$ years; $p=.0002$ ), while no difference was observed in maternal prepregnancy BMI $\left(24.52 \pm 4.32 \mathrm{~kg} / \mathrm{m}^{2}\right.$ of MZ twins' mothers compared to $24.76 \pm 5.11 \mathrm{~kg} / \mathrm{m}^{2}$ of DZ twins' mothers; $p=.570$ ). Mothers of MZ and DZ twins did not differ much regarding their ethnicity, with the vast majority of them being white $(97.19 \%$ and $98.07 \%$ of mothers of MZ and DZ twins, respectively). Table 2 presents the mean differences in birth weight and behavior problems according to zygosity group. As can be seen, MZ twins' mean birth-weight difference was lower than DZ twins' $(246.07 \pm 228.48 \mathrm{~g}$ compared to $295.65 \pm 271.74$ $\mathrm{g} ; p=.004)$. Table 2 also shows mean differences in CBCL scores in $\mathrm{MZ}$ and $\mathrm{DZ}$ twins, subdivided by gender and adjusted by age at survey. Among female-female twin pairs, statistically significantly larger differences were found in $M Z$ twin pairs in the emotional reactiveness scale (1.40 [0.51] and -0.40 [0.49] for females, $\mathrm{MZ}$ and $\mathrm{DZ}$ twin pairs, respectively; $p=.012$ ). On the other hand, DZ twins showed statistically significantly larger differences in somatic complaints $(-0.48$ [0.28] for female MZ twin pairs, and $0.67[0.28]$ for female DZ twin pairs; $p=.004$ ) and withdrawnness (Males: 0.19 [0.13] and -0.34 [0.16] for MZ 
TABLE 3

Intrapair Correlations for Each CBCL Scale, Subdivided Into Zygosity Group

\begin{tabular}{|c|c|c|c|c|}
\hline & \multicolumn{2}{|c|}{$\mathrm{MZ}$} & \multicolumn{2}{|c|}{ DZ } \\
\hline & $r^{a}$ & $r^{b}$ & $r^{a}$ & $r^{b}$ \\
\hline Attention problems & 0.801 & 0.128 & 0.274 & -0.038 \\
\hline Aggressive behavior & 0.865 & 0.044 & 0.639 & 0.070 \\
\hline Total externalizing & 0.888 & 0.083 & 0.623 & 0.042 \\
\hline Emotional reactiveness & 0.136 & 0.122 & -0.093 & 0.052 \\
\hline Anxiety/depression & 0.820 & 0.017 & 0.469 & 0.023 \\
\hline Somatic complaints & 0.600 & -0.084 & 0.251 & 0.023 \\
\hline Withdrawn & 0.856 & -0.094 & 0.404 & -0.004 \\
\hline Total internalizing & 0.807 & 0.055 & 0.559 & 0.048 \\
\hline Sleep problems & 0.863 & -0.114 & 0.540 & -0.019 \\
\hline Total problems & 0.921 & 0.034 & 0.750 & 0.075 \\
\hline 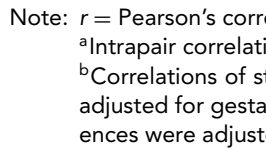 & $\begin{array}{l}\text { of coeff } \\
\text { of raw } \\
\text { ardized }\end{array}$ & $\begin{array}{l}\text { t. } \\
\text { scores. } \\
\text { luals. Bir } \\
\text { x, while } \\
\text { vey and }\end{array}$ & eight d & $\begin{array}{l}\text { nce was } \\
\text { e differ- }\end{array}$ \\
\hline
\end{tabular}

and DZ twins, respectively; $p=.011$. Females: 0.13 [0.15] and -0.38 [0.15] for $\mathrm{MZ}$ and $\mathrm{DZ}$ twin pairs, respectively; $p=.016)$. A marginally significant difference in the mean score was observed in male twin pairs in the sleep problems scale (-0.14 [0.16] and 0.33 [0.18] for MZ and DZ twins, respectively; $p=.051)$. Note that, here, a negative value signifies that the smaller twins at birth scored higher on average than larger birth-weight co-twins, and vice versa.

We computed intrapair correlations by using Pearson's correlation coefficients between the standardized residuals of birth-weight difference, adjusted for gestational age and sex of the pair (i.e., male-male, female-female, or oppositesex), and CBCL score differences, adjusted for age at survey and sex of the pair (Table 3). All residuals were standardized to a mean of zero and a standard deviation of $1 . \mathrm{MZ}$ correlations were higher than DZ correlations only in 4 out of 10 scales (i.e., externalizing and internalizing problems, attention problems, and emotional reactiveness), while in 3 scales, MZ twins' standardized correlations were below the mean value of zero (i.e., sleep problems, somatic complaints, and withdrawn). However, when we computed intrapair twin correlations of raw CBCL scores, MZ twins' correlations were always higher than those of DZ twins (Table 3). Specifically, MZ twins' correlations ranged from 0.136 to 0.921 , with most of them being higher than 0.8 , while DZ twins' correlations ranged from -0.093 to 0.639 . In both cases, the lowest correlations were associated with emotional reactiveness.

\section{Multiple Linear Regression}

Multiple linear regressions were performed first with the absolute birth-weight difference as a continuous variable, and second, after subdividing it into categories of $100 \mathrm{~g}$ difference. No statistically significant association was found when treating birth-weight difference as a continuous variable. However, when subdividing it into birth-weight difference categories, statistically significant associations were found in total problems $(\beta=-5.95 ; 95 \%$ CI $[-11.08,-0.82]$; $p=.023)$, internalizing behavior $(\beta=-4.17$; $95 \%$ CI $[-7.65$, $-0.69] ; p=.019)$ and emotional reactiveness scales $(\beta=-$ 2.70; 95\% CI $[-5.23,-0.17] ; p=.036)$ in MZ twins analyzed as a separate group. Moreover, a borderline statistically significant association was found in sleep problems in MZ twins ( $\beta=-0.84 ; 95 \%$ CI $[-1.69,0.01] ; p=.052)$. No statistically significant association was found neither in $\mathrm{MZ}$ and $\mathrm{DZ}$ twins combined nor in DZ twins analyzed separately.

We then computed expected mean differences for every birth-weight category, subdivided by CBCL scale, in MZ and DZ twins combined (Table 4), MZ twins (Table 5), and DZ twins (Table 6) analyzed separately; $p$ values relative to the whole multiple linear regressions are shown.

In MZ twins analyzed separately, the expected means for the intrapair difference in total problems score ranged from 15.11 (12.03) to -59.29 (25.14). Furthermore, the expected means for internalizing score ranged from 11.27 (8.16) to -38.80 (17.05), while this figure ranged from 7.31 (5.92) to -25.15 (12.38) for emotional reactiveness.

\section{Post-Hoc and Sensitivity Analysis}

Among the independent variables included in the multiple regressions, gestational age was given special attention because of its possible association with childhood neurodevelopment. For this reason, all multiple regressions were repeated without controlling for gestational age. The results were not significantly affected by the exclusion of gestational age (results not shown).

Furthermore, we repeated all the analysis after removing all twin pairs $(n=2$ and $n=9$ for MZ and DZ twins, respectively) with at least one extremely low birth-weight (ELBW) twin (i.e., with a birth weight $\leq 1,000$ g, according to the World Health Organization's definition) from the sample. Again, no difference in the results was observed (results not shown).

\section{Discussion}

The aim of the current study was to replicate the previously reported association between the intrapair birth-weight difference and the intrapair difference in behavior problems, measured by the CBCL questionnaire. As MZ twins share $100 \%$ of their genotype and $100 \%$ of their common environment, if birth-weight discordance in $\mathrm{MZ}$ twins predicts a discordance in CBCL score, then it is plausible to assume a causal association between the two (Vitaro et al., 2009).

The associations between the birth-weight difference and behavior problem scales were first investigated in $\mathrm{MZ}$ and DZ twins combined, but no significant association was identified. The analysis was then repeated in $\mathrm{MZ}$ and $\mathrm{DZ}$ twins separately. The regressions of total CBCL, internalizing problems, and emotional reactiveness score differences over birth-weight difference were significant in MZ but not 
TABLE 4

Expected Mean Difference Score for Increasing Birth-Weight Difference

\begin{tabular}{|c|c|c|c|c|c|c|c|c|c|c|c|c|}
\hline \multirow[b]{2}{*}{ BW difference } & \multicolumn{3}{|c|}{ Total problems } & \multicolumn{3}{|c|}{ Internalizing } & \multicolumn{3}{|c|}{ Externalizing } & & & \\
\hline & Mean & SE & $p$ & Mean & $S E$ & $p$ & Mean & SE & $p$ & & & \\
\hline $0 \mathrm{~g}$ & -4.04 & 6.04 & & 0.98 & 3.38 & & -6.07 & 2.93 & & & & \\
\hline $100 \mathrm{~g}$ & -5.15 & 5.89 & & 0.76 & 3.30 & & -6.29 & 2.86 & & & & \\
\hline $200 \mathrm{~g}$ & -6.26 & 5.83 & & 0.54 & 3.26 & & -6.52 & 2.83 & & & & \\
\hline $300 \mathrm{~g}$ & -7.37 & 5.86 & & 0.32 & 3.28 & & -6.74 & 2.84 & & & & \\
\hline $400 \mathrm{~g}$ & -8.49 & 5.98 & & 0.10 & 3.35 & & -6.97 & 2.90 & & & & \\
\hline $500 \mathrm{~g}$ & -9.60 & 6.18 & & -0.12 & 3.46 & & -7.20 & 3.00 & & & & \\
\hline $600 \mathrm{~g}$ & -10.71 & 6.47 & .13 & -0.33 & 3.62 & .59 & -7.42 & 3.14 & .53 & & & \\
\hline $700 \mathrm{~g}$ & -11.82 & 6.82 & & -0.55 & 3.82 & & -7.65 & 3.31 & & & & \\
\hline $800 \mathrm{~g}$ & -12.93 & 7.22 & & -0.77 & 4.05 & & -7.86 & 3.50 & & & & \\
\hline $900 \mathrm{~g}$ & -14.05 & 7.68 & & -0.99 & 4.30 & & -8.10 & 3.72 & & & & \\
\hline $1,000 \mathrm{~g}$ & -15.16 & 8.17 & & -1.21 & 4.58 & & -8.33 & 3.97 & & & & \\
\hline $1,100 \mathrm{~g}$ & -16.27 & 8.70 & & -1.43 & 4.88 & & -8.55 & 4.22 & & & & \\
\hline$>1,100 \mathrm{~g}$ & -17.38 & 9.26 & & -1.65 & 5.19 & & -8.78 & 4.49 & & & & \\
\hline \multirow[t]{2}{*}{ BW difference } & \multicolumn{3}{|c|}{ Anxiety/depression } & \multicolumn{3}{|c|}{ Emotionally reactive } & \multicolumn{3}{|c|}{ Somatic complaints } & \multicolumn{3}{|c|}{ Withdrawn } \\
\hline & Mean & SE & $p$ & Mean & SE & $p$ & Mean & SE & $p$ & Mean & SE & $p$ \\
\hline $0 \mathrm{~g}$ & 1.42 & 1.11 & & -2.09 & 2.13 & & 2.87 & 1.28 & & -1.23 & 0.72 & \\
\hline $100 \mathrm{~g}$ & 1.45 & 1.09 & & -2.09 & 2.08 & & 2.69 & 1.25 & & -1.31 & 0.70 & \\
\hline $200 \mathrm{~g}$ & 1.48 & 1.07 & & -2.09 & 2.06 & & 2.52 & 1.24 & & -1.39 & 0.69 & \\
\hline $300 \mathrm{~g}$ & 1.51 & 1.08 & & -2.08 & 2.07 & & 2.35 & 1.25 & & -1.46 & 0.70 & \\
\hline $400 \mathrm{~g}$ & 1.54 & 1.10 & & -2.08 & 2.11 & & 2.17 & 1.27 & & -1.54 & 0.71 & \\
\hline $500 \mathrm{~g}$ & 1.58 & 1.14 & & -2.08 & 2.19 & & 2.00 & 1.32 & & -1.62 & 0.74 & \\
\hline $600 \mathrm{~g}$ & 1.61 & 1.19 & .82 & -2.08 & 2.27 & .99 & 1.82 & 1.38 & .26 & -1.70 & 0.77 & .37 \\
\hline $700 \mathrm{~g}$ & 1.64 & 1.26 & & -2.08 & 2.41 & & 1.65 & 1.45 & & -1.78 & 0.81 & \\
\hline $800 \mathrm{~g}$ & 1.67 & 1.33 & & -2.07 & 2.55 & & 1.48 & 1.54 & & -1.86 & 0.86 & \\
\hline $900 \mathrm{~g}$ & 1.70 & 1.42 & & -2.07 & 2.71 & & 1.30 & 1.63 & & -1.94 & 0.91 & \\
\hline $1,000 \mathrm{~g}$ & 1.73 & 1.51 & & -2.07 & 2.89 & & 1.13 & 1.74 & & -2.01 & 1.04 & \\
\hline $1,100 \mathrm{~g}$ & 1.76 & 1.60 & & -2.07 & 3.08 & & 0.95 & 1.85 & & -2.09 & 1.04 & \\
\hline$>1,100 \mathrm{~g}$ & 1.80 & 1.71 & & -2.06 & 3.27 & & 0.78 & 1.97 & & -2.17 & 1.10 & \\
\hline \multirow[t]{2}{*}{ BW difference } & \multicolumn{3}{|c|}{ Aggressive behavior } & \multicolumn{3}{|c|}{ Attention problems } & \multicolumn{3}{|c|}{ Sleep problems } & & & \\
\hline & Mean & $S E$ & $p$ & Mean & SE & $p$ & Mean & SE & $p$ & & & \\
\hline $0 \mathrm{~g}$ & -4.29 & 2.43 & & -1.89 & 1.11 & & 0.20 & 1.13 & & & & \\
\hline $100 \mathrm{~g}$ & -4.57 & 2.37 & & -1.83 & 1.08 & & -0.03 & 1.10 & & & & \\
\hline $200 \mathrm{~g}$ & -4.85 & 2.34 & & -1.77 & 1.07 & & -0.26 & 1.09 & & & & \\
\hline $300 \mathrm{~g}$ & -5.13 & 2.35 & & -1.71 & 1.07 & & -0.49 & 1.10 & & & & \\
\hline $400 \mathrm{~g}$ & -5.40 & 2.40 & & -1.64 & 1.10 & & -0.72 & 1.16 & & & & \\
\hline $500 \mathrm{~g}$ & -5.68 & 2.48 & & -1.58 & 1.33 & & -0.95 & 1.16 & & & & \\
\hline $600 \mathrm{~g}$ & -5.96 & 2.60 & .35 & -1.52 & 1.19 & .64 & -0.18 & 1.21 & .10 & & & \\
\hline $700 \mathrm{~g}$ & -6.24 & 2.74 & & -1.46 & 1.25 & & -1.41 & 1.26 & & & & \\
\hline $800 \mathrm{~g}$ & -6.52 & 2.90 & & -1.39 & 1.32 & & -1.64 & 1.35 & & & & \\
\hline $900 \mathrm{~g}$ & -6.79 & 3.09 & & -1.33 & 1.41 & & -1.87 & 1.44 & & & & \\
\hline $1,000 \mathrm{~g}$ & -7.07 & 3.29 & & -1.27 & 1.50 & & -2.10 & 1.53 & & & & \\
\hline $1,100 \mathrm{~g}$ & -7.35 & 3.50 & & -1.21 & 1.60 & & -2.33 & 1.63 & & & & \\
\hline$>1,100 \mathrm{~g}$ & -7.63 & 3.72 & & -1.14 & 1.70 & & -2.55 & 1.73 & & & & \\
\hline
\end{tabular}

in DZ twins analyzed separately. These results, and especially the very large and clinically significant expected mean differences ranges, suggest that intrauterine factors affecting birth weight are involved in the early development of behavior problems. In fact, as twins are characterized by the same gestational age, a difference in their birth weight is the result of any factor affecting the growth of each individual twin (Pettersson et al., 2015). Modifiable risk factors of birth-weight discordance include low weight gain during pregnancy, advanced maternal age, artificially induced pregnancy, smoking, and hypertensive disorders (Puccio et al., 2014).

Note that all statistically significant beta coefficients are negative, implying a rise in CBCL scores in smaller twins (or a reduction in the larger ones) with the increasing birthweight difference. This is in line with previous studies that have explored the effect of birth-weight discordance on be- havior, cognition, and psychopathology. In fact, the smaller twins in discordant, prematurely born pairs showed lower IQ performances at 3 years of age (Ross et al., 2012) and higher ADHD symptoms at 9 and 12 years (Pettersson et al., 2015) compared to their larger co-twins. Van Os and colleagues examined the association between birth-weight discordance and discordance in CBCL scores in 6- to 17-yearold twins (van Os et al., 2001), reporting a statistically significant, positive association with the total CBCL score. Two aspects differentiate the present study from van Os et al. (2001), the first being that they analyzed only the influence of birth weight on the total CBCL score, while our aim was to determine which specific subscale(s) might be influenced the most by birth weight. The second aspect is that van Os' research group analyzed the linear regressions of relative differences, as opposed to the present study, in which the absolute $\mathrm{CBCL}$ score differences were regressed 
TABLE 5

Expected Mean Difference Score for Increasing Birth-Weight Difference in Monozygotic Twins

\begin{tabular}{|c|c|c|c|c|c|c|c|c|c|c|c|c|}
\hline \multirow[b]{2}{*}{ BW difference } & \multicolumn{3}{|c|}{ Total problems } & \multicolumn{3}{|c|}{ Internalizing } & \multicolumn{3}{|c|}{ Externalizing } & & & \\
\hline & Mean & SE & $p$ & Mean & SE & $p$ & Mean & SE & $p$ & & & \\
\hline $0 \mathrm{~g}$ & 15.11 & 12.03 & & 11.27 & 8.16 & & 6.06 & 5.35 & & & & \\
\hline $100 \mathrm{~g}$ & 9.16 & 10.56 & & 7.10 & 7.16 & & 5.39 & 4.70 & & & & \\
\hline $200 \mathrm{~g}$ & 3.21 & 9.58 & & 2.92 & 6.49 & & 4.74 & 4.26 & & & & \\
\hline $300 \mathrm{~g}$ & -2.74 & 9.24 & & -1.25 & 6.27 & & 4.08 & 4.11 & & & & \\
\hline $400 \mathrm{~g}$ & -8.69 & 9.61 & & -5.42 & 6.52 & & 3.42 & 4.28 & & & & \\
\hline $500 \mathrm{~g}$ & -14.64 & 10.63 & & -9.59 & 7.21 & & 2.76 & 4.73 & & & & \\
\hline $600 \mathrm{~g}$ & -20.59 & 12.12 & .02 & -13.76 & 8.22 & .02 & 2.11 & 5.39 & .57 & & & \\
\hline $700 \mathrm{~g}$ & -26.54 & 13.93 & & -17.94 & 9.45 & & 1.45 & 6.20 & & & & \\
\hline $800 \mathrm{~g}$ & -33.49 & 15.97 & & -22.11 & 10.83 & & 0.79 & 7.10 & & & & \\
\hline $900 \mathrm{~g}$ & -38.44 & 18.14 & & -26.28 & 12.30 & & 0.13 & 8.07 & & & & \\
\hline $1,000 \mathrm{~g}$ & -44.39 & 20.41 & & -30.45 & 13.84 & & -0.53 & 9.08 & & & & \\
\hline $1,100 \mathrm{~g}$ & -50.34 & 22.75 & & -34.63 & 15.43 & & -1.18 & 10.12 & & & & \\
\hline$>1,100 \mathrm{~g}$ & -56.29 & 25.14 & & -38.80 & 17.05 & & -1.84 & 11.18 & & & & \\
\hline \multirow[t]{2}{*}{ BW difference } & \multicolumn{3}{|c|}{ Anxiety/depression } & \multicolumn{3}{|c|}{ Emotionally reactive } & \multicolumn{3}{|c|}{ Somatic complaints } & \multicolumn{3}{|c|}{ Withdrawn } \\
\hline & Mean & SE & $p$ & Mean & SE & $p$ & Mean & SE & $p$ & Mean & SE & $p$ \\
\hline $0 \mathrm{~g}$ & 0.65 & 2.11 & & 7.31 & 5.92 & & 1.95 & 2.80 & & 1.41 & 0.99 & \\
\hline $100 \mathrm{~g}$ & 0.41 & 1.86 & & 4.60 & 5.20 & & 0.91 & 2.46 & & 1.19 & 0.87 & \\
\hline $200 \mathrm{~g}$ & 0.17 & 1.68 & & 1.90 & 4.72 & & -0.14 & 2.23 & & 0.97 & 0.79 & \\
\hline $300 \mathrm{~g}$ & -0.06 & 1.62 & & -0.81 & 4.55 & & -1.18 & 2.15 & & 0.75 & 0.76 & \\
\hline $400 \mathrm{~g}$ & -0.30 & 1.69 & & -3.51 & 4.74 & & -2.22 & 2.24 & & 0.53 & 0.79 & \\
\hline $500 \mathrm{~g}$ & -0.54 & 1.87 & & -6.21 & 5.24 & & -3.26 & 2.48 & & 0.30 & 0.88 & \\
\hline $600 \mathrm{~g}$ & -0.78 & 2.13 & .60 & -8.92 & 5.97 & .04 & -4.31 & 2.83 & .09 & 0.08 & 1.00 & .30 \\
\hline $700 \mathrm{~g}$ & -1.01 & 2.45 & & -11.62 & 6.86 & & -5.35 & 3.25 & & -0.14 & 1.15 & \\
\hline $800 \mathrm{~g}$ & -1.25 & 2.81 & & -14.33 & 7.86 & & -6.39 & 3.72 & & -0.36 & 1.32 & \\
\hline $900 \mathrm{~g}$ & -1.49 & 3.19 & & -17.03 & 8.94 & & -7.43 & 4.23 & & -0.58 & 1.50 & \\
\hline $1,000 \mathrm{~g}$ & -1.73 & 3.59 & & -19.74 & 10.05 & & -8.48 & 4.76 & & -0.81 & 1.68 & \\
\hline $1,100 \mathrm{~g}$ & -1.96 & 4.00 & & -22.44 & 11.21 & & -9.52 & 5.30 & & -1.03 & 1.88 & \\
\hline$>1,100 \mathrm{~g}$ & -2.20 & 4.42 & & -25.15 & 12.38 & & -10.56 & 5.86 & & -1.25 & 2.07 & \\
\hline \multirow[t]{2}{*}{ BW difference } & \multicolumn{3}{|c|}{ Aggressive behavior } & \multicolumn{3}{|c|}{ Attention problems } & \multicolumn{3}{|c|}{ Sleep problems } & & & \\
\hline & Mean & SE & $p$ & Mean & SE & $p$ & Mean & SE & $p$ & & & \\
\hline $0 \mathrm{~g}$ & 5.39 & 5.10 & & 0.57 & 1.78 & & -0.45 & 1.99 & & & & \\
\hline $100 \mathrm{~g}$ & 4.89 & 4.48 & & 0.46 & 1.57 & & -1.29 & 1.75 & & & & \\
\hline $200 \mathrm{~g}$ & 4.39 & 4.07 & & 0.35 & 1.42 & & -2.13 & 1.59 & & & & \\
\hline $300 \mathrm{~g}$ & 3.90 & 3.92 & & 0.24 & 1.37 & & -2.97 & 1.53 & & & & \\
\hline $400 \mathrm{~g}$ & 3.40 & 4.08 & & 0.13 & 1.43 & & -3.81 & 1.59 & & & & \\
\hline $500 \mathrm{~g}$ & 2.90 & 4.51 & & 0.02 & 1.58 & & -4.65 & 1.76 & & & & \\
\hline $600 \mathrm{~g}$ & 2.41 & 5.14 & 0.65 & -0.09 & 1.80 & 0.78 & -5.49 & 2.01 & 0.05 & & & \\
\hline $700 \mathrm{~g}$ & 1.91 & 5.91 & & -0.20 & 2.07 & & -6.33 & 2.31 & & & & \\
\hline $800 \mathrm{~g}$ & 1.41 & 6.78 & & -0.30 & 2.37 & & -7.17 & 2.64 & & & & \\
\hline $900 \mathrm{~g}$ & 0.92 & 7.70 & & -0.41 & 2.69 & & -8.01 & 3.01 & & & & \\
\hline $1,000 \mathrm{~g}$ & 0.42 & 8.66 & & -0.52 & 3.03 & & -8.86 & 3.38 & & & & \\
\hline $1,100 \mathrm{~g}$ & -0.08 & 9.66 & & -0.63 & 3.37 & & -9.70 & 3.77 & & & & \\
\hline$>1,100 \mathrm{~g}$ & -0.57 & 10.67 & & -0.74 & 3.73 & & -10.54 & 4.16 & & & & \\
\hline
\end{tabular}

over the absolute birth-weight difference. Although this differential approach limits the comparability between the two studies, our choice of presenting expected mean differences for $100 \mathrm{~g}$ birth-weight difference was led by the purpose of presenting more interpretable results for clinicians and parents.

Previous heritability analysis showed that internalizing and externalizing problem behaviors in young twins are influenced by genetic and environmental factors, with the vast majority of the observed variance explained by the genetic factors (van der Valk et al., 1998). The analysis of discordances in MZ twins allows one to focus on unique environmental factors only, which are thought to explain 25$32 \%$ of the observed variance in internalizing and externalizing problems (van der Valk et al., 1998), and about 22\% of the variance in negative emotionality (Schumann et al., 2017). However, when we analyzed MZ twins alone, the val- ues of $R^{2}$ indicate that each of the association considered accounted only for about $8-11 \%$ of the variance. At the same time, the expected mean differences in CBCL scores at $0 \mathrm{~g}$ birth-weight difference strongly diverged from the expected value of zero. These results could signify that other factors are likely to influence twins' behavioral development. For example, it is possible that non-reported intrauterine growth restriction affected the smaller twins' psychological development independently from birth weight, although a sensitivity analysis removing all pairs with ELBW twins did not show different results. Alternatively, other risk factors able to affect the individuals' behavior independently from their co-twins (i.e., increasing the difference between the two) could have an influence on the birth-weight difference behavior problems association.

Among the environmental factors that might affect the behavioral development of children, low birth weight 
TABLE 6

Expected Mean Difference Score for Increasing Birth-Weight Difference in Dizygotic Twins

\begin{tabular}{|c|c|c|c|c|c|c|c|c|c|c|c|c|}
\hline \multirow[b]{2}{*}{ BW difference } & \multicolumn{3}{|c|}{ Total problems } & \multicolumn{3}{|c|}{ Internalizing } & \multicolumn{3}{|c|}{ Externalizing } & & & \\
\hline & Mean & SE & $p$ & Mean & SE & $p$ & Mean & SE & $p$ & & & \\
\hline $0 \mathrm{~g}$ & 0.32 & 9.84 & & 0.11 & 5.20 & & -6.29 & 4.85 & & & & \\
\hline $100 \mathrm{~g}$ & -1.77 & 8.78 & & 0.35 & 4.64 & & -6.93 & 4.33 & & & & \\
\hline $200 \mathrm{~g}$ & -3.85 & 7.98 & & 0.58 & 4.21 & & -7.57 & 3.93 & & & & \\
\hline $300 \mathrm{~g}$ & -5.94 & 7.51 & & 0.82 & 3.97 & & -8.21 & 3.70 & & & & \\
\hline $400 \mathrm{~g}$ & -8.02 & 7.44 & & 1.06 & 3.93 & & -8.85 & 3.67 & & & & \\
\hline $500 \mathrm{~g}$ & -10.11 & 7.78 & & 1.29 & 4.11 & & -9.49 & 3.83 & & & & \\
\hline $600 \mathrm{~g}$ & -12.19 & 8.48 & .24 & 1.53 & 4.48 & .80 & -10.13 & 4.18 & .46 & & & \\
\hline $700 \mathrm{~g}$ & -14.28 & 9.46 & & 1.77 & 5.00 & & -10.78 & 4.66 & & & & \\
\hline $800 \mathrm{~g}$ & -16.36 & 10.64 & & 2.00 & 5.62 & & -11.42 & 5.24 & & & & \\
\hline $900 \mathrm{~g}$ & -18.45 & 11.97 & & 2.24 & 6.32 & & -12.06 & 5.90 & & & & \\
\hline $1,000 \mathrm{~g}$ & -20.53 & 13.39 & & 2.48 & 7.07 & & -12.70 & 6.60 & & & & \\
\hline $1,100 \mathrm{~g}$ & -22.68 & 14.89 & & 2.71 & 7.87 & & -13.34 & 7.34 & & & & \\
\hline$>1,100 \mathrm{~g}$ & -24.70 & 16.44 & & 2.95 & 8.69 & & -13.98 & 8.10 & & & & \\
\hline \multirow[t]{2}{*}{ BW difference } & \multicolumn{3}{|c|}{ Anxiety/depression } & \multicolumn{3}{|c|}{ Emotionally reactive } & \multicolumn{3}{|c|}{ Somatic complaints } & \multicolumn{3}{|c|}{ Withdrawn } \\
\hline & Mean & $S E$ & $p$ & Mean & SE & $p$ & Mean & SE & $p$ & Mean & SE & $p$ \\
\hline $0 \mathrm{~g}$ & 1.69 & 1.85 & & -3.41 & 2.98 & & 2.96 & 2.06 & & -1.17 & 1.28 & \\
\hline $100 \mathrm{~g}$ & 1.94 & 1.65 & & -3.25 & 2.66 & & 2.88 & 1.84 & & -1.25 & 1.14 & \\
\hline $200 \mathrm{~g}$ & 2.18 & 1.50 & & -3.08 & 2.41 & & 2.80 & 1.67 & & -1.33 & 1.03 & \\
\hline $300 \mathrm{~g}$ & 2.43 & 1.41 & & -2.91 & 2.27 & & 2.72 & 1.57 & & -1.41 & 0.97 & \\
\hline $400 \mathrm{~g}$ & 2.67 & 1.40 & & -2.75 & 2.25 & & 2.63 & 1.56 & & -1.49 & 0.96 & \\
\hline $500 \mathrm{~g}$ & 2.92 & 1.46 & & -2.58 & 2.35 & & 2.55 & 1.63 & & -1.57 & 1.01 & \\
\hline $600 \mathrm{~g}$ & 3.16 & 1.59 & .46 & -2.41 & 2.56 & .76 & 2.47 & 1.77 & .83 & -1.66 & 1.10 & .72 \\
\hline $700 \mathrm{~g}$ & 3.41 & 1.78 & & -2.25 & 2.86 & & 2.39 & 1.98 & & -1.74 & 1.23 & \\
\hline $800 \mathrm{~g}$ & 3.66 & 2.00 & & -2.08 & 3.22 & & 2.31 & 2.23 & & -1.82 & 1.38 & \\
\hline $900 \mathrm{~g}$ & 3.90 & 2.25 & & -1.92 & 3.62 & & 2.23 & 2.50 & & -1.90 & 1.55 & \\
\hline $1,000 \mathrm{~g}$ & 4.15 & 2.52 & & -1.75 & 4.05 & & 2.15 & 2.80 & & -1.98 & 1.74 & \\
\hline $1,100 \mathrm{~g}$ & 4.39 & 2.80 & & -1.58 & 4.50 & & 2.07 & 3.12 & & -2.06 & 1.93 & \\
\hline$>1,100 \mathrm{~g}$ & 4.64 & 3.09 & & -1.42 & 4.97 & & 1.99 & 3.44 & & -2.14 & 2.13 & \\
\hline \multirow[t]{2}{*}{ BW difference } & \multicolumn{3}{|c|}{ Aggressive behavior } & \multicolumn{3}{|c|}{ Attention problems } & \multicolumn{3}{|c|}{ Sleep problems } & & & \\
\hline & Mean & SE & $p$ & Mean & $S E$ & $p$ & Mean & $S E$ & $p$ & & & \\
\hline $0 \mathrm{~g}$ & -4.26 & 3.88 & & -2.22 & 1.90 & & 1.27 & 1.91 & & & & \\
\hline $100 \mathrm{~g}$ & -4.83 & 3.47 & & -2.27 & 1.69 & & 0.98 & 1.71 & & & & \\
\hline $200 \mathrm{~g}$ & -5.41 & 3.15 & & -2.33 & 1.54 & & 0.69 & 1.46 & & & & \\
\hline $300 \mathrm{~g}$ & -5.98 & 2.96 & & -2.39 & 1.45 & & 0.41 & 1.46 & & & & \\
\hline $400 \mathrm{~g}$ & -6.55 & 2.94 & & -2.44 & 1.44 & & 0.12 & 1.44 & & & & \\
\hline $500 \mathrm{~g}$ & -7.12 & 3.07 & & -2.50 & 1.50 & & -0.16 & 1.51 & & & & \\
\hline $600 \mathrm{~g}$ & -7.70 & 3.35 & .41 & -2.56 & 1.64 & .87 & -0.45 & 1.65 & .41 & & & \\
\hline $700 \mathrm{~g}$ & -8.27 & 3.73 & & -2.61 & 1.82 & & -0.73 & 1.84 & & & & \\
\hline $800 \mathrm{~g}$ & -8.84 & 4.20 & & -2.67 & 2.05 & & -1.02 & 2.07 & & & & \\
\hline $900 \mathrm{~g}$ & -9.42 & 4.72 & & -2.73 & 2.31 & & -1.30 & 2.32 & & & & \\
\hline $1,000 \mathrm{~g}$ & -9.99 & 5.29 & & -2.78 & 2.58 & & -1.59 & 2.60 & & & & \\
\hline $1,100 \mathrm{~g}$ & -10.56 & 5.88 & & -2.84 & 2.87 & & -1.87 & 2.89 & & & & \\
\hline$>1,100 \mathrm{~g}$ & -11.13 & 6.49 & & -2.90 & 3.17 & & -2.16 & 3.19 & & & & \\
\hline
\end{tabular}

(LBW) has been frequently highlighted. As Drvaric and colleagues discussed in their review (Drvaric et al., 2013), extremely low birth-weight (ELBW) infants are at increased risk of emotional regulation issues, internalizing and externalizing behavior problems, and lower IQ, compared to normal-weight infants. In the present study, we did not observe any influence of ELBW on the results of the linear regression analyses, probably due to the low number of twin pairs with at least one ELBW twin (i.e., 11 out of 480 ). With regards to the association between birth weight and neurologic soft signs, Breslau et al. (2000) reported a higher risk of soft signs, along with internalizing, externalizing, and attention problems in children born with a LBW. Finally, analyzing infants' temperament, Riese (1994) reported that larger twins were more irritable, more difficult to soothe, and more active while awake and during sleep, compared to their smaller co-twins. Although these results seem to devi- ate substantially from the present and previously published articles, this could be due to the relatively small sample size and the twins' age, that is, only a few days, which may have influenced infants' response to the experimental stimuli.

The present study comes with some limitations. Data were collected by means of an online, maternally reported questionnaire, although a commonly used and validated one. This has precluded the collection of any data regarding chorionicity and intrauterine growth. Furthermore, because of the volunteer-based nature of the study, it was susceptible to selection bias, in that mothers of twins with problematic behaviors might have been more interested in participating in the research. However, although parental ratings are subject to several types of limitations, they are still considered a critically important source of information in behavioral genetics research. In fact, even though psychologists and psychiatrics would provide more detailed 
and less biased description of children's behavior, their observations would involve stressful, standardized situations, and a laboratory setting in which observed responses and reactions may not reflect children's usual behavior. On the opposite, parents' ratings, while not perfect, are thought to better summarize children's normal reactions to everyday stimuli, especially during the preschool years (Saudino et al., 2000). Furthermore, we had no data regarding parenting behaviors. It is possible that differential parenting practices toward co-twins might naturally derive from birthweight discordance, as parents might tend to provide more attention to their smaller, weaker child, which might in turn differentially influence twins' behavior (Asbury et al., 2003). Other externalizing and internalizing risk factors (i.e., familial socio-economic status, maternal education levels, substance abuse, and psychopathology) reported by Carneiro et al. (2016) were not available for the current study. However, these factors would probably not have affected the results in the current research design, as they are factors common to the co-twins and, therefore, likely to increase their similarities instead of their differences.

In conclusion, this study reports a clinically significant association of MZ twins' absolute birth-weight difference with total and internalizing problems and emotional reactiveness score differences, calculated with the CBCL $1 \frac{1}{2-}$ 5. This clearly indicates that unique environmental factors (i.e., those causing the different birth weight) are involved in young twins' psychological and behavioral development. However, we cannot exclude the role of other non-shared environmental influences, such as chorionicity and differential parental treatment between co-twins. Future studies should include these data for elucidating their role in the psychological development of young twins born discordant for birth weight.

\section{Acknowledgments}

The authors wish to thank all participating families. The study was supported by the University of Birmingham (grant number: GAS1168).

\section{Conflict of Interest}

None.

\section{Ethical Standards}

The authors assert that all procedures contributing to this work comply with the ethical standards of the relevant national guidelines on human experimentation and with the Helsinki Declaration of 1975, as revised in 2008, and has been approved by the University of Birmingham Ethics Committee.

\section{Informed Consent}

Informed consent was obtained from all individual participants included in the study by the University of Birmingham Ethics Committee.

\section{References}

Achenbach, T. M., \& Rescorla, L. A. (2000). Manual for the ASEBA preschool forms \& profiles: Child behavior checklist for ages $1 / 2-5$, language development survey, Caregiver Teacher report form; an integrated system of multi-informant assessment. Burlington, VT: ASEBA.

Antoniou, E. E., Fowler, T., Reed, K., Southwood, T. R., McCleery, J. P., \& Zeegers, M. P. (2014). Maternal prepregnancy weight and externalising behaviour problems in preschool children: A UK-based twin study. BMJ Open, 4, e005974.

Asbury, K., Dunn, J. F., Pike, A., \& Plomin, R. (2003). Nonshared environmental influences on individual differences in early behavioral development: A monozygotic twin differences study. Child Development, 74, 933-943.

Bartels, M., van den Oord, E. J. C. G., Hudziak, J. J., Rietveld, M. J. H., van Beijsterveldt, C. E. M., \& Boomsma, D. I. (2004). Genetic and environmental mechanisms underlying stability and change in problem behaviors at ages 3, 7, 10, and 12. Developmental Psychology, 40, 852-867.

Breslau, N., Chilcoat, H. D., Johnson, E. O., Andreski, P., \& Lucia, V. C. (2000). Neurologic soft signs and low birthweight: Their association and neuropsychiatric implications. Biological Psychiatry, 47, 71-79.

Carneiro, A., Dias, P., \& Soares, I. (2016). Risk factors for internalizing and externalizing problems in the preschool years: Systematic literature review based on the child behavior checklist $1 \frac{1}{2}-5$. Journal of Child and Family Studies, 25, 2941-2953.

Drvaric, L. A., Van Lieshout, R. J., \& Schmidt, L. A. (2013). Linking early adversity, emotion dysregulation, and psychopathology: The case of extremely low birth weight infants. Child Development Research, Article ID 203061, $1-9$.

Goldsmith, H. H. (1991). A zygosity questionnaire for young twins: A research note. Behavior Genetics, 21, 257-269.

Jokela, M., Ferrie, J., \& Kivimak̈i, M. (2009). Childhood problem behaviors and death by midlife: The British National Child Development Study. Journal of the American Academy of Child and Adolescent Psychiatry, 48, 19-24.

Kent, E. M., Breathnach, F. M., Gillan, J. E., McAuliffe, F. M., Geary, M. P., Daly, S., ... Morrison, J. J. (2012). Placental pathology, birthweight discordance, and growth restriction in twin pregnancy: Results of the ESPRiT Study. American Journal of Obstetrics and Gynecology, 207, 220.e221.

Knopik, V. S., Neiderhiser, J. M., de Geus, E., \& Boomsma, D. (2016). The importance of the prenatal environment in behavioral genetics: Introduction to special issue. Behavior Genetics, 46, 281-285.

Mankuta, D., Goldner, I., \& Knafo, A. (2010). Intertwin birth weight differences and conduct problems in early child- 
hood. Archives of Pediatrics \& Adolescent Medicine, 164, 457-461.

Pettersson, E., Sjol̈ander, A., Almqvist, C., Anckarsä̈er, H., D’Onofrio, B. M., Lichtenstein, P., \& Larsson, H. (2015). Birth weight as an independent predictor of ADHD symptoms: A within-twin pair analysis. Journal of Child Psychology and Psychiatry, and Allied Disciplines, 56, 453-459.

Puccio, G., Giuffré, M., Piccione, M., Piro, E., Malerba, V., \& Corsello, G. (2014). Intrauterine growth pattern and birthweight discordance in twin pregnancies: A retrospective study. Italian Journal of Pediatrics, 40, 43.

Riese, M. L. (1994). Neonatal temperament in full-term twin pairs discordant for birth weight. Journal of Developmental and Behavioral Pediatrics, 15, 342-347.

Ross, G. S., Krauss, A. N., \& Perlman, J. M. (2012). Physical growth and cognitive abilities in concordant versus discordant birth weight twins at three years old. Early Human Development, 88, 753-756.

Saudino, K. J., Cherny, S. S., \& Plomin, R. (2000). Parent ratings of temperament in twins: Explaining the 'too low' DZ correlations. Twin Research and Human Genetics, 3, 224233.

Schumann, L., Boivin, M., Paquin, S., Lacourse, E., Brendgen, M., Vitaro, F., ... Booij, L. (2017). Persistence and innovation effects in genetic and environmental factors in negative emotionality during infancy: A twin study. PLoS One, 12, e0176601.
Sourander, A., Jensen, P., Davies, M., Niemela“, S., Elonheimo, H., Ristkari, T., ... Almqvist, F. (2007). Who is at greatest risk of adverse long-term outcomes? The Finnish From a Boy to a Man Study. Journal of the American Academy of Child \& Adolescent Psychiatry, 46, 1148-1161.

StataCorp. (2013). Stata statistical software: Release 13. College Station, TX: StataCorp LP.

Van Der Ende, J., Verhulst, F. C., \& Tiemeier, H. (2016). The bidirectional pathways between internalizing and externalizing problems and academic performance from 6 to 18 years. Development and Psychopathology, 28, 855-867.

van der Valk, J. C., Verhulst, F. C., Stroet, T. M., \& Boomsma, D. I. (1998). Quantitative genetic analysis of internalising and externalising problems in a large sample of 3-year-old twins. Twin Research and Human Genetics, 1, 25-33.

van Os, J., Wichers, M., Danckaerts, M., Van Gestel, S., Derom, C., \& Vlietinck, R. (2001). A prospective twin study of birth weight discordance and child problem behavior. Biological Psychiatry, 50, 593-599.

Victoria, A., Mora, G., \& Arias, F. (2001). Perinatal outcome, placental pathology, and severity of discordance in monochorionic and dichorionic twins. Obstetrics and Gynecology, 97, 310-315.

Vitaro, F., Brendgen, M., \& Arseneault, L. (2009). The discordant MZ-twin method: One step closer to the holy grail of causality. International Journal of Behavioral Development, $33,376-382$. 